\title{
Desain Intervensi Melalui Pendekatan Teori Levin Untuk Mereduksi Perceraian
}

\author{
Defiana Gunawan \\ Desy Kumala Sari \\ Feren Agnes \\ Margaret \\ Universitas Tarumanagara \\ efianagunawan49@gmail.com, desykumalaa05@gmail.com, agnesferen@gmail.com, \\ margareteffendy@gmail.com
}

\begin{abstract}
Abstrak
Penelitian ini bertujuan untuk menjabarkan desain intervensi dengan cara mereduksi intensi perceraian berdasarkan teori Levin. Adapun metode penelitian yang penulis gunakan adalah penelitian kualitatif dengan metode pengukuran Participacy Action Research (PAR) yang melibatkan partisipan sebanyak tiga orang dari anggota komunitas SPINMOTION (Single Parents in Motion) Jogja. Badan Pusat Statistik menyatakan bahwa pada tahun 2015, perceraian di Indonesia sendiri mencapai 347.256 orang, hal ini terus meningkat dari 2013. Terdapat berbagai macam penyebab dari perceraian, dalam penelitian ini kami lebih menekankan pada perceraian akibat ketidaksetiaan (unfaithfullness).

Desain intervensi yang dilakukan kepada pasangan yang sudah menikah atau yang baru akan menikah agar mereduksi intensi perceraian di kemudian hari yaitu dengan Focus Group Design (FGD), melalui seminar atau penyuluhan, dan pemutaran film berdasarkan pengalaman dari orang-orang yang mengalami perceraian. Hasil penelitian menemukan bahwa perlu dilakukan desain intervensi dengan cara mereduksi intensi perceraian sehingga untuk mencapai tujuan sasaran jangka panjang ini, maka dalam jangka pendek dan menengah perlu dilakukan upaya untuk merubah pola pikir para pasangan muda agar tidak terjebak dalam pola pikir yang keliru mengenai pernikahan maupun perceraian.
\end{abstract}

Kata kunci: intervensi sosial, pernikahan, perceraian, ketidaksetiaan, pasangan.

\begin{abstract}
This study aims to describe the design of the intervention by reducing divorce intentions based on the Levin theory. The research method that I use is qualitative research using PAR (Participacy Action Research) measurement method which involves three participants from the Jogja SPINMOTION (Single Parents in Motion) community members. The Central Bureau of Statistics stated that in 2015 divorce in Indonesia alone reached 347,256 people, this continues to increase from 2013. There are various kinds of causes of divorce, in this study we emphasize divorce due to unfaithfulness.

The design of the intervention carried out to married couples or newly married to reduce the intention of divorce in the future, namely by FGD (Focus Group Design), through seminars or counseling, and film screenings based on the experience of people who experience divorce. The results of the study found that intervention design was needed by reducing the intention of divorce so that in order to achieve this long-term goal, efforts should be made in the short and medium term to change the mindset of young couples so that they are not trapped in mistaken thinking about marriage or divorce.
\end{abstract}

Keyword: Social intervention, marriage, divorce, unfaithfullness, couple.

(C) 2018 Universitas Muria Kudus 


\section{PENDAHULUAN}

Pada era ini lingkungan sosial sangat dinamis dan terbuka. Ada banyak lingkungan yang dimasuki remaja, salah satunya ketika mereka mulai mengenal pergaulan, kenal dengan lawan jenis yang menapaki tahap pacaran hingga menjurus pada seks bebas dan pernikahan (Tsany, 2015). Pernikahan merupakan bentuk penyatuan antara dua orang dalam sebuah ikatan yang pada umumnya berlangsung sekali dalam rentang hidup manusia. Tujuan dari pernikahan itu sendiri adalah mendapatkan keturunan, menyatukan dua keluarga, memenuhi kebutuhan biologis, memperoleh intimacy, mendapat dukungan sosial, memperoleh perlindungan dari pasangan, memperoleh kebahagiaan, menuju ke dalam kehidupan yang lebih baik, dan sebagainya.

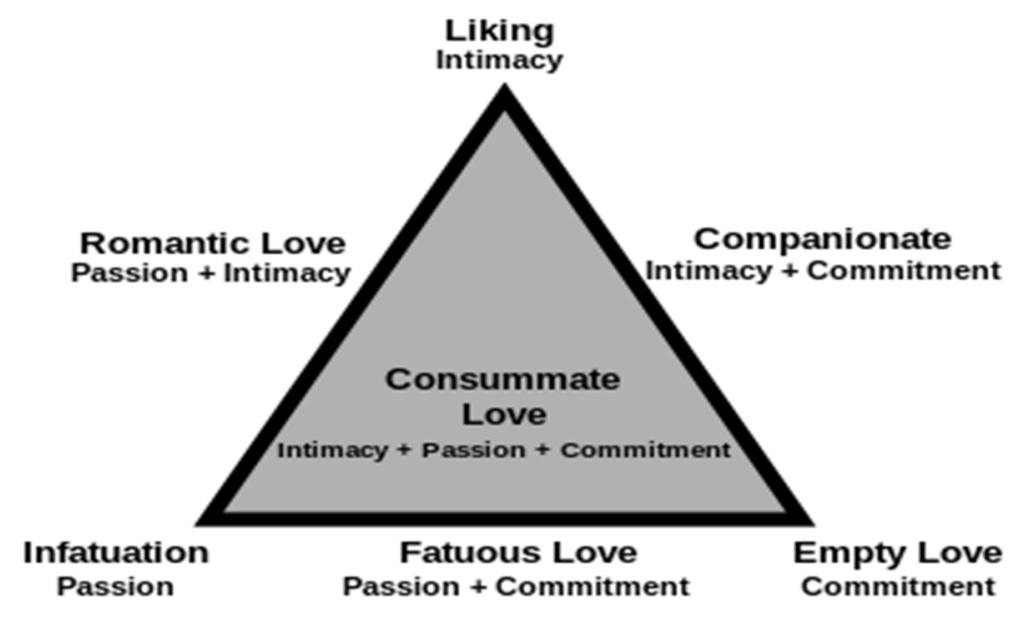

\section{Gambar 1. Triangular Theory of Love}

Dalam Triangular Theory of Love dari Sternberg ini terdapat tiga komponen yang mempengaruhi percintaan yaitu intimacy (bagian atas segitiga), passion (bagian kiri segitiga), dan commitment (bagian kanan segitiga) (Sternberg, 1986). Komponen intimacy sama dengan perasaan kedekatan, keterhubungan, dan keterikatan dalam hubungan cinta. Hal ini termasuk perasaan hangat dalam suatu hubungan. Komponen passion sama dengan dorongan yang mengarahkan ke sesuatu yang romantis, ketertarikan secara fisik. Komponen passion ini termasuk sebagai sumber motivasi yang mendorong pengalaman passion dalam suatu hubungan. Sedangkan komponen komitmen, dalam waktu pendek merupakan keputusan untuk mencintai seseorang dan dalam waktu panjang komitmen mengatur percintaan. Menurut Sternberg, kondisi cinta yang ideal akan tercipta apabila ketiga komponen cinta tersebut seimbang sehingga membentuk segitiga sama sisi (yang menandakan bentuk cinta yang ideal sesuai dengan teori segitiga cinta yaitu The Triangular Theory of Love). Penelitian Sternberg \& Grajek (1984) menunjukan bahwa intimacy termasuk perasaan keinginan untuk meningkatkan kesejahteraan orang yang dicintai, komunikasi secara intim dengan orang yang dicintai, mengalami kebahagiaan dengan orang yang dicintai, 
mendapatkan dukungan emosional dari orang yang dicintai, saling berbagi dengan orang yang dicintai, dan sebagainya. Komponen passion termasuk apa yang Hatfield dan Walster (1981) katakan sebagai "suatu keadaan kerinduan yang intens untuk bersatu dengan yang lain". Dalam hubungan cinta, kebutuhan seksual mungkin mendominasi dalam komponen ini. Namun, kebutuhan lain, seperti harga diri, kepuasan, pengasuhan, afiliasi, dominasi, penyerahan, dan aktualisasi diri, juga dapat berkontribusi pada komponen passion. Kekuatan berbagai kebutuhan ini pasti akan bervariasi di antara orang-orang, situasi, dan jenis hubungan cinta. Komponen passion pasti akan sangat tinggi dan memiliki hubungan timbal balik yang interaktif dengan intimacy. Komponen komitmen terdiri dari dua aspek, jangka pendek dan jangka panjang. Jangka pendek adalah keputusan seseorang untuk mencintai. Aspek jangka panjang adalah komitmen untuk mempertahankan cinta itu. Berdasarkan penjelasan panjang di atas, mengenai tingginya angka perceraian tiap tahunnya serta tujuantujuan dari banyak pasangan agar dapat menikah dan hidup harmonis bersama pasangannya hingga maut memisahkan, makaPenulis memutuskan untuk meneliti tentang pentingnya desain intervensi untuk mereduksi perceraian.

Menurut Clinebell \& Clinebell (2005) periode awal pernikahan merupakan masa penyesuaian diri, dan krisis muncul saat pertama kali memasuki jenjang pernikahan. Lamanya masa pacaran sebelum menikah, tidak menentukan sukses tidaknya hubungan antar personal antara pasangan suami istri (Anjani \& Suryanto, 2006). Kesuksesan dalam sebuah pernikahan bukan hanya ditentukan berdasarkan waktu, tetapi juga berdasarkan seberapa dalam mengenal pasangan masing-masing.

Selain berlandaskan cinta, dalam pernikahan juga dibutuhkan komitmen, kepercayaan, kejujuran, dan kesetiaan. Apabila dalam sebuah pernikahan terdapat pasangan yang tidak mampu untuk setia dengan pasangannya mungkin pernikahan tersebut tidak dapat dipertahankan dan berujung pada perceraian. Perselingkuhan yang terjadi dalam sebuah rumah tangga dapat terjadi karena berbagai faktor, diantaranya kesibukan masing-masing, kurang komunikasi, jarang bertemu, jarang menghabiskan waktu bersama pasangan atau keluarga, tidak mendapatkan haknya sebagai seorang pasangan, tidak bahagia, mendapatkan perlakuan tidak adil, terjadi kekerasan, pergaulan yang salah, dan sebagainya. Bentuk ketidaksetiaan dari pasangan juga dapat berupa hadirnya orang ketiga dalam rumah tangga (terjadi perselingkuhan).

Daniel (Kosasih, 2009) mengatakan bahwa perselingkuhan adalah perbuatan layaknya pasangan suami istri yang sah seseorang dengan orang lain, tetapi bukan pasangan resminya, sifatnya lebih kepada memenuhi perasaan senang bagi sang pelaku. Kebanyakan perselingkuhan yang terjadi dalam rumah tangga dilakukan oleh suami. Situasi tersebut mungkin dapat dikarenakan suami yang lebih sering berada di luar rumah untuk bekerja dan bertemu dengan banyak orang. Beberapa penelitian menunjukkan bahwa prevalensi 
perselingkuhan lebih tinggi untuk pria di semua budaya (Greely, 1994; Wiederman, 1997) terlepas dari apa jenis hubungan utama (menikah atau berkencan) dan apakah perselingkuhan diukur sebagai "keinginan untuk", "melakukan" atau "telah melakukan" (Blow \& Hartnett, 2005; Schmitt, 2003).

Sepanjang era sejarah di seluruh dunia (Fisher, 1992) dan bahkan sebelum pernikahan (diantara mahasiswa di perguruan tinggi dan orang-orang yang belum menikah) perselingkuhan telah diketahui umum dilaporkan sekitar 60\% ke atas (Schmitt \& Buss, 2001; Allen \& Baucom, 2006). Data statistik tahun 2005 Direktorat Jendral Pembinaan Peradilan Agama menunjukan bahwa perselingkuhan telah menjadi virus keluarga nomor empat di Indonesia (Mualim, 2007). Data yang dihimpun dari BKKBN pada tahun 2013 terdapat 2.218.130 pernikahan dan 324.527 kasus perceraian. Angka tersebut terus meningkat sekitar $25 \%$ setiap tahunnya.

Beberapa pasangan yang menjadi korban dari ketidaksetiaan pasangannya memutuskan untuk bercerai. Hal tersebut dilakukan karena rasa sakit hati yang mereka alami. Terutama untuk kaum wanita, mereka memutuskan untuk bercerai karena merasa sudah tidak dihargai layaknya seorang istri. Meskipun pada awalnya mereka berusaha untuk mempertahankan keutuhan rumah tangga. Menurut Spring (2006) wanita lebih mungkin berupaya untuk memperbaiki hubungan dan mempertahankan, sedangkan laki-laki lebih mempunyai kecenderungan untuk mengakhirinya dan mencari pengganti jika mereka dalam posisi korban perselingkuhan.

Beberapa orang memutuskan untuk bercerai karena ketidaksetiaan yang dilakukan oleh pasangan mereka. Mereka mengalami konflik antara tetap bertahan dalam pernikahan karena masih mencintai suami dan anak-anak dengan ingin segera bercerai karena perbuatan suami telah melanggar prinsip utama pernikahan mereka (Snyder, Baucom, \& Gordon, 2008; Hargrave). Berdasarkan laporan penelitian, 90\% dari semua perceraian melibatkan perselingkuhan. Konsep dari ketidaksetiaan (perselingkuhan) telah didefinisikan sebagai pelanggaran komitmen terhadap kesetiaan seksual oleh satu atau dua orang anggota dari hubungan yang memiliki komitmen, dyadic sex dalam konteks hubungan monogami, keterlibatan romantis atau emosional yang melanggar komitmen terhadap hubungan dengan pasangan sesungguhnya, dan pelanggaran norma terhadap pasangan yang mengatur tingkat keintiman secara emosional atau fisik dengan orang-orang di luar hubungan berkomitmen (Drigotas \& Barta, 2001; Glass, 2002; Zare, 2011; Mark, Janssen \& Milhausen, 2009). Beberapa dimensi perselingkuhan, termasuk perzinaan, prostitusi pasangan yang sudah menikah, dengan santai menggoda seseorang dan atau melakukan percakapan seksual secara eksplisit dengan seseorang di luar hubungan pasangan yang utama; pertukaran seksual tanpa keterlibatan romantis serta semua nuansa seksual dan keterlibatan romantis (Handy, 1998; Glass \& Wright, 1992). 
Perselingkuhan didefinisikan sebagai ketidaksetiaan karena tidak dapat diandalkan dan kecurangan pada pasangan hubungan yang terjadi meskipun ada komitmen secara eksklusif. Namun, sebagian besar literatur membagi perselingkuhan ke dalam kategori yang lebih spesifik, termasuk perselingkuhan seksual, ketidaksetiaan emosional, gabungan perselingkuhan dan perselingkugan internet secara seksual dan emosional (Glass, 1985).

Mackenzie (2011) mengklasifikasikan ketidaksetiaan ke dalam tiga jenis: perselingkuhan seksual, perselingkuhan emosional dan ketidaksetiaan investasi penuh. Menurut Mackenzie (2011), perselingkuhan seksual adalah hubungan dengan seseorang di luar pernikahan yang murni atau terutama seksual (ada sedikit atau tidak ada ikatan emosional).

Atkins et al (2001) menemukan bahwa orang yang berpendidikan tinggi lebih cenderung melakukan hubungan seks di luar nikah. Mereka menyimpulkan bahwa terdapat hubungan yang signifikan antara perceraian dengan tingkat pendidikan dan korelasi antara pendidikan dengan perselingkuhan, dan hanya signifikan untuk pasangan yang bercerai (Atkins et al, 2001). Charkas \& Oelsner (2004) menunjukkan bahwa perselingkuhan dan jumlah pasangan seksual keduanya dipengaruhi oleh genetik. Perselingkuhan yang lebih spesifik $(41 \%)$ dan jumlah pasangan seksual (38\%) diwariskan. Jika dikaitkan dengan kepribadian, perselingkuhan secara signifikan terkait dengan rendahnya keramahan (low agreeableness) dan rendahnya kesadaran (low conscientiousness). Schmitt dan Buss (2000) menemukan bahwa mereka yang memiliki tingkat agreeableness dan conscientiousness lebih tinggi dalam hubungan secara eksklusif yang berarti mereka kurang cenderung untuk tidak setia.

Drigotas et al (1999) membagi alasan ketidaksetiaan ke dalam lima kategori yaitu, sexuality-emotional satisfaction, social context, attitudes-norms dan revenge-hostility. Akhirnya, perselingkuhan sebagai balas dendam secara tradisional merupakan alasan umum untuk tidak setia di antara mereka, pasangan yang sudah menikah (Buss \& Shackelford 1997, Johson 1972, Greene, Lee \& Lusting 1974). Sebagian besar studi tentang konsekuensi perselingkuhan menunjukkan hasil negatif seperti: kemarahan, kehilangan kepercayaan, penurunan kepercayaan diri secara pribadi dan seksual, merusak harga diri, takut ditinggalkan, dan gelombang pembenaran untuk meninggalkan pasangan (Charny \& Parnass, 1995).

Kebanyakan para wanita korban perselingkuhan yang memutuskan untuk bercerai mengalami guncangan secara mental dari masyarakat sekitar. Hal tersebut karena status mereka yang sudah menjadi seorang single parent. Kebanyakan dari mereka mengalami keterpurukan pada awal masa perceraian karena keadaan yang tidak lagi sama seperti sebelumnya. Mereka harus dihadapkan dengan banyak penilaian negatif dari orang-orang disekitar, mereka juga harus berusaha menjaga anak mereka, menjadi tulang punggung untuk 
keluarga, berperan double dalam keluarga (menjadi ayah sekaligus ibu untuk anak mereka). Namun, kebanyakan dari mereka menyadari bahwa mereka harus mampu bangkit dari keterpurukan dan fokus pada masa depan. Mereka tidak ingin di pandang sebelah mata oleh banyak orang karena status mereka sebagai seorang single parent.

Beberapa dari antara mereka yang menjadi korban ketidaksetiaan dari pasangannya mengaku memiliki banyak pelajaran yang dapat mereka ambil. Beberapa dari mereka mengaku tertipu oleh penampilan pasangan mereka, dan juga mereka mengaku membuat keputusan yang cepat untuk menikah di usia muda. Begitu juga dalam hal pengambilan keputusan menikah, menurut Murcahya (2010) dalam penelitiannya menyatakan bahwa faktor paling dominan dalam pengambilan keputusan menikah muda dipengaruhi oleh faktor lingkungan, yaitu budaya dan adat istiadat setempat, serta teman sebaya atau komunitas orang-orang sekitar pelaku.

Diantara dari mereka mengaku merasa bersyukur karena telah ditunjukan bahwa pasangannya merupakan orang yang tidak baik untuk dirinya sebelum semuanya berlarut. Bahkan tidak jarang diantara mereka bergabung dalam berbagai komunitas single parent untuk menambah koneksi, berbagi pengalaman mengenai kehidupan mereka, dan tidak jarang diantara mereka memotivasi atau memberi masukan kepada pasangan-pasangan muda di luar sana untuk berhati-hati dalam memilih pasangan hidup agar hal yang mereka alami tidak terjadi pada semua orang.

Papalia (2001) mengatakan bahwa perceraian diibaratkan ketika menjalani sebuah operasi, menyakitkan dan menimbulkan trauma, akan tetapi harus dijalani untuk mendapatkan kehidupan yang lebih baik. Individu harus mampu bertahan menghadapi berbagai situasi setelah perceraian. Bertahan dalam keadaan tertekan, dan bahkan berhadapan dengan kesengsaraan (adversity) atau trauma yang dialami dalam kehidupannya (Reivich\& Shatte, 2002).

\section{METODE PENELITIAN}

\section{Partisipan}

Partisipan dalam penelitian kali ini merupakan tiga orang anggota komunitas SPINMOTION (Single Parents in Motion), yang merupakan komunitas single parents di seluruh Indonesia. SPINMOTION ini merupakan komunitas yang berpusat di Jogja. Ketiga orang partisipan untuk penelitian ini merupakan seorang wanita yang mengalami perceraian akibat hadirnya orang ketiga dalam rumah tangga mereka. Partisipan pertama berinisial $\mathrm{P}$ yang berusia 33 tahun. Partisipan kedua berinisial E yang berusia 37 tahun. Partisipan ketiga berinisial $S$ yang berusia 25 tahun. 


\section{Prosedur Penelitian}

Penelitian dilakukan melalui teknik kualitatif yaitu melakukan wawancara secara mendalam kepada ketiga orang subjek. Wawancara yang dilakukan kepada ketiga orang subjek dilakukakan di tempat, lokasi, dan waktu yang berbeda. Sebelum wawancara dilakukan, partisipan diminta untuk mengisi dan menandatangani informed consent yang telah disediakan sebagai bentuk persetujuan bahwa subjek bersedia menjadi partisipan dalam penelitian kali ini. Peneliti juga meminta izin untuk melakukan perekaman suara kepada partisipan ketika proses wawancara berlangsung untuk tujuan verbatim. Pertanyaan yang diajukan ketika wawancara berlangsung berlandaskan pada teori yang diambil dari beberapa jurnal dan buku. Pedoman wawancara dalam bentuk pertanyaan tersebut telah disiapkan oleh peneliti sebelum wawancara dilakukan. Selain melakukan wawancara, penulis juga melakukan observasi terhadap partisipan selama proses wawancara berlangsung. Hal ini bertujuan untuk melihat kesesuaian antara jawaban yang diberikan oleh partisipan dengan ekspresi atau bahasa tubuh yang diperlihatkan.

\section{Pengukuran}

Metode pengukuran yang diterapkan penelitian ini melalui Parcipatory Action Research (PAR) atau Penelitian Aksi Partisipatif. Berhubung menggunakan metode penelitian ini, oleh karena itu penelitian ini berjalan beriringan dengan aksi dan intervensi. Setiap langkah penelitian yang kami lakukan tidak lepas dari aksi intervensi yang sesuai, tujuannya agar para pasangan-pasangan muda yang baru menikah atau akan menikah bertambah secara kesiapan dan pengetahuan. Langkah-langkah metodologis selama penelitian ini meliputi beberapa tahapan : (1) Observasi dan membangun rapport. Rapport sangat penting dalam penelitian ini karena perceraian menjadi topik yang cukup sensitif apalagi bagi orang yang baru bercerai. Oleh karena itu rapport sangat dibutuhkan agar subjek dapat berani, nyaman dalam menceritakan pengalamannya tersebut. (2) Untuk memperoleh data kualitatif maka dilakukan wawancara secara mendalam pada subjek. Dari wawancara secara mendalam ini diharapkan dapat mengetahui atau mengukur hal-hal yang menyebabkan terjadinya perceraian terutama perceraian karena masalah ketidaksetiaan. (3) Peneliti bergabung dalam komunitas chat SPINMOTION untuk mengetahui informasi lebih mendalam mengenai masalah-masalah yang dialami oleh para anggota khususnya yang mengalami perceraian serta mendapatkan informasi dari psikolog dan dokter yang bergabung dalam komunitas mengenai berbagai hal yang berkaitan dengan masalah yang dialami. (4) Setelah memperoleh cukup data, peneliti melakukan observasi pada pasangan-pasangan yang akan menikah atau baru menikah. (5) Peneliti akan mensosialisasikan pada pasangan yang baru menikah atau akan menikah untuk lebih berhati-hati dalam menentukan keputusan untuk menikah karena menikah cukup sekali, hal ini juga sesuai dengan nilai dari komunitas SPINMOTION. Walaupun komunitasnya sebagian besar anggotanya janda atau duda tetapi 
mereka tetap memegang teguh nilai pernikahan cukup sekali dalam seumur hidup. Lebih baik mencegah dari pada mengobati (sudah terjadi).

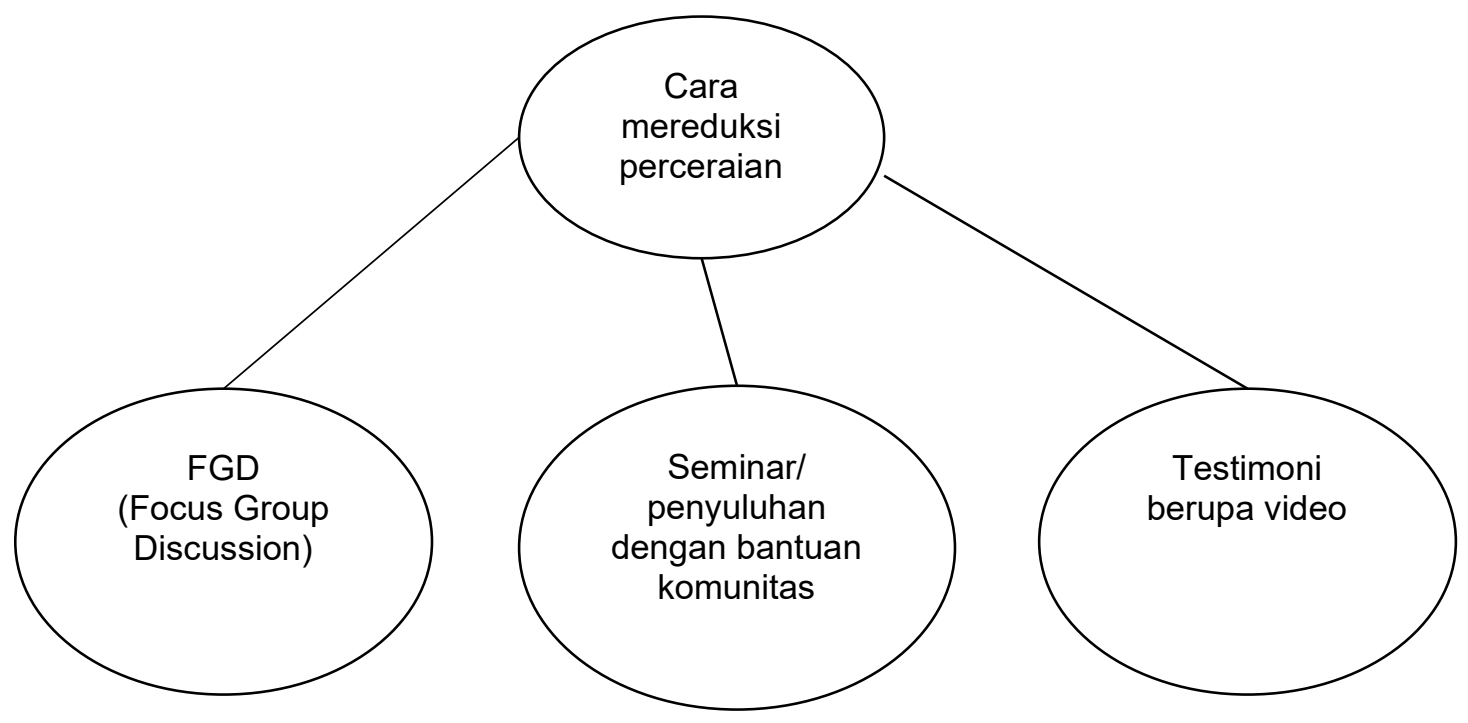

\section{HASIL DAN PEMBAHASAN}

Berdasarkan teori yang didapatkan mengenai pencegahan infidelity/unfaithfullness/ketidaksetiaan. Tahap perubahan belief dan behavior pada pasangan muda atau pasangan yang akan menikah supaya tidak terjadi perceraian yang tidak diinginkan dilakukan melalui beberapa tahap. Tahap pertama adalah mencari tahu penyebab-penyebab apa yang menyebabkan terjadinya ketidaksetiaan dalam pernikahan. Dalam buku berjudul "SOCIAL PROBLEM: Causes, Consequences, Intervention" oleh Levin, dinyatakan penyebab-penyebab dari perceraian. Perceraian dilihat dari berbagai sisi yaitu secara individual, kultural, dan struktural.

Jika dilihat pada perceraian karena ketidaksetiaan pasangan, penyebab secara individual bisa dilihat dari masing-masing pasangan, seperti mudah percaya dengan pasangannya tanpa mencari tahu bibit bebet bobot terlebih dahulu karena terbujuk sikap pasangan yang dianggap (belief) baik, romantis dan bertanggung jawab dengan masa pengenalan yang singkat. 


\begin{tabular}{|c|c|}
\hline $\begin{array}{l}\text { Kondisi sebelum intervensi } \\
\text { - } \quad \text { Pasangan muda yang akan } \\
\text { menikah percaya bahwa } \\
\text { laki-laki yang dia akan } \\
\text { nikahi tepat karena } \\
\text { dianggap baik hati, } \\
\text { romantis, dan bertanggung } \\
\text { jawab } \\
\text { Masyarakat percaya bahwa } \\
\text { ketidaksetiaan dari suami// } \\
\text { istri disebabkan oleh salah } \\
\text { satu pasangan karena tidak } \\
\text { mampu memuaskan }\end{array}$ & $\begin{array}{l}\text { Kondisi yang diharapkan setelah } \\
\text { intervensi } \\
\text { - Pasangan muda yang akan } \\
\text { menikah lebih berhati-hati } \\
\text { sebelum memutuskan menikah } \\
\text { sehingga perceraian dapat } \\
\text { dihindarkan } \\
\text { - Pasangan menyadari bahwa } \\
\text { pernikahan (hubungan jangka } \\
\text { panjang) membutuhkan } \\
\text { intimacy, passion, dan } \\
\text { commitment. } \\
\text { Pasangan muda yang akan } \\
\text { menikah atau baru menikah } \\
\text { dapat belajar dari pengalaman } \\
\text { buruk yang sudah orang lain } \\
\text { alami sehingga dapat } \\
\text { mengatasi berbagai konflik } \\
\text { dengan bijak }\end{array}$ \\
\hline
\end{tabular}

\section{Diagram 1. Capaian Teknis}

Penyebab secara individual juga bisa dikarenakan terlalu percaya dengan penampilan, karena penampilan selalu dianggap sebagai kepribadian seseorang. Contohnya: laki-laki bertato dan rambut bercat rambut warna kuning selalu dianggap sebagai anak lakilaki yang nakal (stigma masyarakat). Padahal belum tentu kepribadian laki-laki yang bertato itu justru lebih buruk dibandingkan laki-laki berkemeja dan berpakaian rapi. Selanjutnya ada penyebab secara kultural, seperti pandangan masyarakat yang menganggap laki-laki punya banyak perempuan dirasa lebih menarik. Terdapat studi yang dilakukan para peneliti dari University St. Andrews dan University of Exeter menunjukkan bahwa perempuan menilai seorang laki-laki menarik jika ada perempuan lain menaksirnya.

Sedangkan penyebab secara struktural adalah karena adanya aturan yang memperbolehkan untuk beristri lebih dari satu. Beberapa penyebab dari berbagai sisi inilah yang menyebabkan munculnya perceraian karena ketidaksetiaan (orang ketiga). Tahap kedua adalah merubah cara berpikir (belief) yang salah dari para pasangan muda yang baru menikah ataupun akan menikah. Bahwa pernikahan itu hanya cukup sekali oleh karena itu perlu berhati-hati dan perlu mempertimbangkan banyak hal. Tahap ketiga, pasangan muda atau yang akan menikah lebih berhati-hati saat memutuskan menikah, jadi lebih mempertimbangkan beberapa hal terlebih dahulu, dan bagi yang sudah menikah saat menghadapi konflik diharapkan lebih bijak setelah mendapatkan saran-saran dari yang sudah berumah tangga. Perceraian karena ketidaksetiaan ini akan terus meningkat jika penyebabnya sendiri tidak diatasi (diagram 2). 


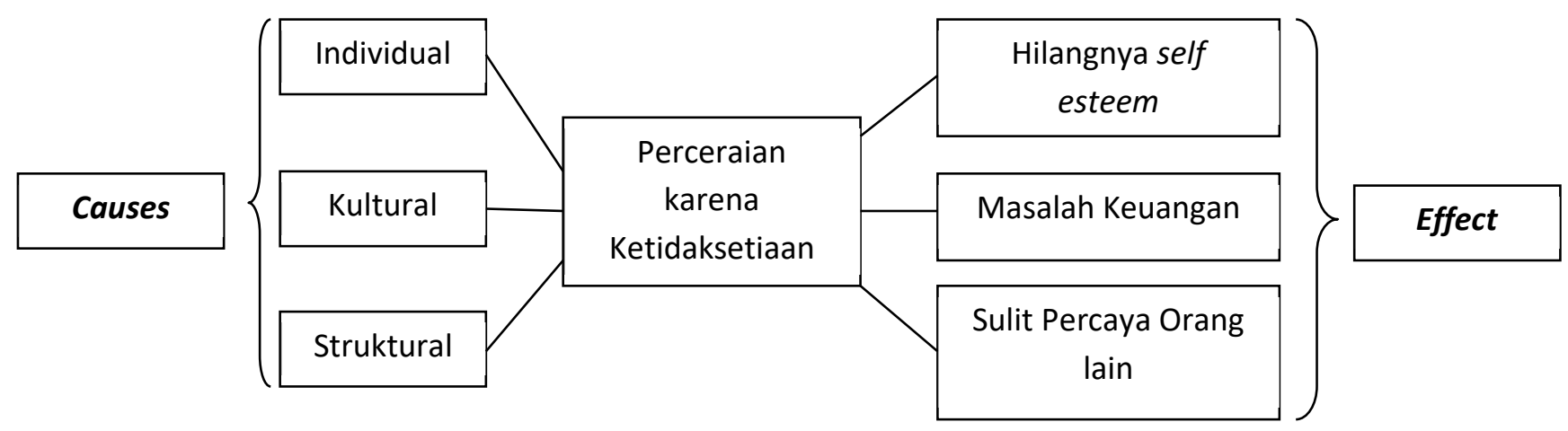

\section{Diagram 2. Causes dan Effect Perceraian}

\section{SIMPULAN}

Agar pasangan yang baru menikah atau yang akan menikah dapat merasakan hasil intervensinya, intervensi sosial yang pertama mengusahakan agar para pasangan yang akan menikah dapat lebih mempertimbangkan dengan seksama sebelum memutuskan menikah karena menikah cukup hanya sekali dan yang baru menikah diharapkan dapat belajar dari pasangan yang gagal dalam berumah tangga sehingga dapat lebih bijak mengatasi masalah diawal pernikahannya. Dengan pasangan muda lebih mempertimbangkan sebelum menikah, sehingga mereka lebih berhati-hati dan memikirkan apakah pasangannya memang memiliki komitmen, passion, dan intimacy untuk membangun hubungan serius dengannya. Untuk mencapai tujuan sasaran jangka panjang ini, maka dalam jangka pendek dan menengah perlu dilakukan upaya untuk merubah pola pikir para pasangan muda agar tidak terjebak dalam pola pikir yang keliru mengenai pernikahan maupun perceraian. Pencapaian tujuan intervensi tentu nantinya akan dilakukan secara bertahap dalam sebuah proses panjang yang reflektif, realistis dan konsisten. Berhubung laporan ini dibuat hanya dalam bentuk desain, akan lebih baik jika laporan ini dapat diteruskan menjadi percobaan intervensi pada pasangan muda yang akan menikah atau telah menikah. Memang hasil yang dirasakan setelah intervensi memakan cukup banyak waktu lama. Dari uraian diatas dapat disimpulkan bahwa cara mereduksi perceraian yang dianggap efektif dan berdampak adalah dengan menggunakan tiga metode mereduksi perceraian di atas yaitu dengan FGD (Focus Group Design), seminar dan pemaparan video.

\section{DAFTAR PUSTAKA}

Allen, E.S. \& Baucom, D.H. (2006). Dating, marital, and hypothetical extradyadic involvements: How do they compare? The Journal of Sex Research, 43: 307-317. 
Anjani, C. \& Suryanto. (2006). Pola Penyesuaian Perkawinan pada Periode Awal. Insan 8 (3), Fakultas Psikologi Universitas Airlangga.

Badan Pusat Statistik. (2015). Nikah, Talak, dan Cerai, serta Rujuk, 2012 - 2015. Diunduh dari https://www.bps.go.id/linkTableDinamis/view/id/893.

Clinebell, H. J. \& Clinebell, C. H. (2005). The Intimate Marriage (online). Diunduh pada tanggal 28 Februari 2006.

Drigotas, S. \& Barta, W. (2001). The cheating heart: Scientific explorations of infidelity. Current Directions in Psychological Science, 10, 5, 177-180.

Fisher, H.E. (1992). Anatomy of love: The natural history of monogamy, adultery and divorce. New York: W.W. Norton.

Glass, S. P. \& Wright, T. (1992). Justifications for extramarital relationships: The association between attitudes, behaviours and gender. Journal of Sex Research, 29: 361-387.

Glass, S.P. (2002). Couple therapy after the trauma of infidelity. In A.S. Gurman \& N.S. Jacobson (Eds.). Clinical handbook of couple therapy ( $3^{\text {rd }}$ ed.). pp 488-507. New York: Guilford.

Glass, W. T. L. (1985). Sex difference in type of extramarital involvement and marital satisfaction. Sex Roles:18.

Greeley, A. M. (1991). Faithful attraction. New York: A Tom Doherty Associates Book.

Handy, B. (1998). How we really feel about fidelity: a new poll suggests America hate the sin, not the sinner. But only to a point. Time August 31.

Kosasih, Suryani, D. (2009). Pengaruh Komunikasi Interpersonal antara Suami Istri terhadap Kecenderungan Berselingkuh Suami. Skripsi. Fakultas Psikologi Universitas Merdeka, Malang.

Mark, K.P., Janssen, E. \& Milhausen, R.R. (2009). Infidelity in heterosexual couples: Demographic, Interpersonal and Personality-related predictors of extradyadic sex. Archives of Sexual Behaviour: Springer Science + Business Media.

Mualim. (2007). Data statistik perselingkuhan di Indonesia. Republika.co.id.

Schmitt, D.P. \& Buss, D.M. (2001). Human mate poaching: Tactics and temptations for infiltrating existing mateships. Journal of Personality and Social Psychology, 80: 894917.

Sternberg, R. J. (1986). A Triangulary Theory of Love. Psychological Review, 93(2), 119-135.

Tsany, F. (2015). Trend Pernikahan Dini di Kalangan Remaja (Studi Kasus di Kabupaten Gunung Kidul Yogyakarta Tahun 2009-2012). Jurnal IImiah Sosiologi Agama. Volume 9, No. 1, Januari-Juni 2015.

Wiederman, M.W. (1997). Prevalence and correlates in a national survey. Journal of Sex Research, 34,170. 
Zare, B. (2011). Review of studies on infidelity. Third International Conference on Advanced Management Science IPEDR, 19 LACSIT Press. 